\title{
Integrative machine learning analysis of multiple gene expression profiles in cervical cancer
}

\author{
Mei Sze Tan ${ }^{1}$, Siow-Wee Chang ${ }^{\text {Corresp., }}{ }^{1}$, Phaik Leng Cheah ${ }^{2}$, Hwa Jen Yap ${ }^{3}$ \\ ${ }^{1}$ Bioinformatics Programme, Institute of Biological Sciences, Faculty of Science, University of Malaya, Kuala Lumpur, Malaysia \\ 2 Department of Pathology, Faculty of Medicine, University of Malaya, Kuala Lumpur, Malaysia \\ 3 Department of Mechanical Engineering, Faculty of Engineering, University of Malaya, Kuala Lumpur, Malaysia \\ Corresponding Author: Siow-Wee Chang \\ Email address: siowwee@um.edu.my
}

Although most of the cervical cancer cases are reported to be closely related to the Human Papillomavirus (HPV) infection, there is a need to study genes that stand up differentially in the final actualization of cervical cancers following HPV infection. In this study, we proposed an integrative machine learning approach to analyse multiple gene expression profiles in cervical cancer in order to identify a set of genetic markers that are associated with and may eventually aid in the diagnosis or prognosis of cervical cancers. The proposed integrative analysis is composed of three steps, namely, (i) gene expression analysis of individual dataset; (ii) meta-analysis of multiple datasets and (iii) feature selection and machine learning analysis. As a result, 21 gene expressions were identified through the integrative machine learning analysis which including seven supervised and one unsupervised methods. A functional analysis with GSEA (Gene Set Enrichment Analysis) was performed on the selected 21-gene expression set and showed significant enrichment in 9-potential-gene-expression signature, namely PEG3, SPON1, BTD and $R P L P 2$ (upregulated genes) and PRDX3, COPB2, LSM3, SLC5A3 and AS1B (downregulated genes). 


\section{Integrative machine learning analysis of multiple gene}

\section{3 expression profiles in cervical cancer.}

4 Mei Sze Tan ${ }^{1}$, Siow-Wee Chang ${ }^{1 *}$, Phaik Leng Cheah ${ }^{2}$, Hwa Jen Yap ${ }^{3}$

5 'Bioinformatics Programme, Institute of Biological Sciences, Faculty of Science, University of 6 Malaya, Kuala Lumpur, Malaysia.

$7 \quad{ }^{2}$ Department of Pathology, Faculty of Medicine, University of Malaya, Kuala Lumpur, Malaysia.

$8 \quad{ }^{3}$ Department of Mechanical Engineering, Faculty of Engineering, University of Malaya, Kuala

9 Lumpur, Malaysia,

$10 \quad{ }^{*}$ Corresponding author

11 Siow-Wee Chang

12 siowwee@um.edu.my / changsiowwee@gmail.com

\section{Abstract}

14 Although most of the cervical cancer cases are reported to be closely related to the Human

15 Papillomavirus (HPV) infection, there is a need to study genes that stand up differentially in the

16 final actualization of cervical cancers following HPV infection. In this study, we proposed an

17 integrative machine learning approach to analyse multiple gene expression profiles in cervical

18 cancer in order to identify a set of genetic markers that are associated with and may eventually aid

19 in the diagnosis or prognosis of cervical cancers. The proposed integrative analysis is composed

20 of three steps, namely, (i) gene expression analysis of individual dataset; (ii) meta-analysis of 
21 multiple datasets and (iii) feature selection and machine learning analysis. As a result, 21 gene expressions were identified through the integrative machine learning analysis which including seven supervised and one unsupervised methods. A functional analysis with GSEA (Gene Set Enrichment Analysis) was performed on the selected 21-gene expression set and showed significant enrichment in 9-potential-gene-expression signature, namely PEG3, SPON1, BTD and RPLP2 (upregulated genes) and PRDX3, COPB2, LSM3, SLC5A3 and AS1B (downregulated genes).

\section{Introduction}

Cervical cancer, ranked $4^{\text {th }}$ most common cancer [1] among women worldwide, caused 279,311 mortality cases in the year 2015 [2]. It is the $3^{\text {rd }}$ most common cancer (7.7\%) among Malaysian females [3]. Most of the development of cervical cancer is linked to the infection of the Human Papillomavirus (HPV) that passes to the human host during sexual activity. The other mentioned risk factors include smoking, imbalanced diet and family history [4-6]. However, as in many cancers, it is conceivable that genetic pathways play a role in the development of cervical cancer.

Microarray technology has been used to simultaneously identify a large number of gene expressions that may be associated with a particular cancer. Reports of prognostically predictive genes have been identified by whole genome microarray in cancer. Hu et al. [7] showed that miR200a and miR-9 were associated with cervical cancer outcome while Aziz et al. [8], reported on 19 common genes that were predictive in colorectal cancers. Meta-analysis is touted to solve the problems of low statistical power of studies, to be able to analyze intersected genes between

42 datasets, extract the optimum values across multiple datasets and identify the most commonly 
43 expressed genes [9] [10]. Based on our literature review, we believed that this is one of the first

44 few studies which involves meta-analysis using multiple cervical cancer microarray datasets.

45 Despite many approaches were introduced in the previous meta-analysis study, biased issue that

46 is caused by merging datasets from different platforms and experiments is a hot topic among the

47 field. The studies in [11-14] carried out meta-analysis in various type of cancers to find the

48 significant genes in certain diseases such as breast cancer, paediatric B-acute lymphoblastic

49 leukaemia (B-ALL), ovarian cancer and etc. Trendily, most of these studies were done by using

50 the original datasets that varied from different platforms. As the original datasets contained noisy

51 data such as the extreme values, thus the bias effects from each of the respective datasets might be

52 strong.

53 Furthermore, until to-date, most of the previous studies are either using statistical analysis methods

54 [11-14] or machine learning-based methods [12-19] in carrying out the meta-analysis. Due to

55 different measurements being used in analysing the expression activities in the genes, there is no

56 way in comparing the feasibility of both methods in a meta-analysis. Hence, by combining both

57 the statistical and machine learning methods, meaningful insights could be discovered. Favourable

58 features from both of the methods are integrated and fully utilized in carrying out the meta-analysis

59 in this study.

60 To address the shortcomings of meta-analysis we attempted to build a system which integrates

61 machine learning with meta-analysis to improve the quality of the data acquired. The whole

62 process encompasses (i) Gene expression analysis of individual dataset; (ii) meta-analysis of

63 multiple datasets; and (iii) feature selection (FS) \& machine learning analysis. We report our

64 findings using our proposed integrative analysis in identifying genes which could be integral in 
65 the development of cervical cancers, a cancer in which understanding has moved significantly

66 forward and awaits unravelling of possible genetic intermediaries in the carcinogenetic process.

\section{Materials and Methods}

In brief, our approach commences with the gene expression analysis of individual cervical cancer microarray datasets obtained from publicly available sources and to detect the genes that perform most significantly in each of the dataset. The most significant gene sets from each dataset are combined and intersected to form a larger dataset in the first stage. Microarray gene expression meta-analysis is performed using the combined dataset in the second stage. For the final stage, several FS and machine learning methods as well as a functional analysis by gene set enrichment analysis (GSEA) will be carried out to identify a more precise set of potential gene markers in cervical cancer biology.

\section{Microarray Datasets}

All the data used are from the public website National Center Biotechnology Information Gene Expression Omnibus (NCBI GEO) (http://www.ncbi.nlm.nih.gov/geo). A search using the keywords "cervical cancer" and "microarray" was carried out. To ensure the accurateness and purity of the resultant 104 (before $5^{\text {th }}$ January 2017) datasets, filtration was performed by manually reviewing each dataset using the following criteria. To gain entry into this study, the dataset must 1) contain expression profiling by array types, 2) use CEL raw files, and 3) be studies that involve cervical cancer as the main subject. Finally, only four cervical cancer microarray gene expression datasets (see Table 1) could be entered for further analysis.

\section{Table 1 Details of the four microarray datasets used in this research.}


87 All analyses of the data were performed in R programming environment (version 3.3.2).

88

89

90

91

92

93

94

95

96

97

98

\section{Integrative approach of meta-analysis and machine learning}

The aim of the proposed integrative approach is to fully utilize the benefits from both of the statistical analysis and the machine learning approaches in carrying out gene expression metaanalysis, in order to find out the most significant gene markers in cervical cancer. Generally, the proposed integrative analysis is composed of three stages, namely, (i) gene expression analysis of individual dataset; (ii) meta-analysis of multiple datasets and (iii) feature selection and machine learning analysis. The proposed integrative method is illustrated as in Figure 1. At the first stage, gene expression analysis of individual dataset was carried out where 10,000 differentially expressed genes from each dataset were selected by using Linear Models for Microarray Analysis (LIMMA). This process was repeated on four datasets. In stage (ii), meta-analysis of four datasets was carried out. Intersection process was done in order to obtain the intersected genes among the four datasets. A set of upregulated and downregulated genes were selected and ranked accordingly by using Rank Prod at the end of stage (ii). In stage (iii), eight FS and machine learning approaches were applied in order to identify the common optimum genes.

\section{Figure 1 Framework for the proposed integrative approach of meta-analysis and machine learning in gene expression profiling of cervical cancer.}

*DE- differential expression value

Stages of the integrative approach are as detailed below:

\section{Stage (i) Gene expression analysis of individual dataset}

The data were first filtered to select out cancer samples (removal of normal samples) to ensure that the activities of the genes presented in the normal samples would not affect the analysis. Among 
111 the four sets of microarray data used in our study, only microarray data of GSE9750 [22] is based

112 on the Affymetrix Human Genome U133A Array [HG-U133A] platform. The other three datasets

113 are based on Affymetrix Human Genome U133 Plus 2.0 Array [HG-U133_Plus_2]. Therefore, it

114 is necessary to pre-process and normalize all of the raw level probe data across the platforms to

115 reduce bias caused by the different platforms. Quantile algorithm were applied to normalize the

116 data and the data were $\log 2$-transformed according to all the samples median.

117 Then, gene expression analysis was performed on each of the microarray datasets. RMA

118 normalization from affy function in Bioconductor package R was carried out for every sample in

119 the dataset to create expression values that are normalized and background corrected.

120 After that, differential gene expression analysis was carried out to select the top 10000

121 differentially expressed genes from individual dataset using Linear Models for Microarray

122 Analysis (LIMMA) [24]. In this stage, the rare and over-extremely expressed genes in every

123 dataset were eliminated by using moderated $t$-statistics of LIMMA so that bias errors from each

124 dataset could be reduced when combining the datasets to become a larger dataset.

125 R package of limma was used to rank and select out the top differential expressed genes. The 126 differentially-expressed genes were filtered using adjusted p-value of $<0.05$ and ranked based 127 according to the p-values. In this study, the same gene expression analysis was repeated on all the 128 four datasets.

129 Hence, this stage is treated as quality control of the dataset which is going to use in the stage (ii) 130 analysis as genes produced by this stage are consistently different between the group according to 131 the LIMMA statistics. 
134 The aim of this stage is to select the genes that show upregulated and downregulated activities in 135 cervical cancer. Four microarray gene expression datasets that contained top 10,000 genes each 136 (selected in the stage(i)) were combined in the intersection process by identifying the intersected 137 genes found among the four datasets and merging all samples to form a single, larger sample size 138 dataset (meta-dataset).

139 Next, meta-analysis was conducted by using RankProd [25] package in $\mathrm{R}$ to analyse the intersected 140 genes. With the default value of $p<0.05, F D R<0.05$ as the cut-off point, RankProd ranked the 141 genes into two group: upregulated $(\mathrm{FC}>1$, $\mathrm{php}<0.01)$ and downregulated genes $(\mathrm{FC}<1, \mathrm{php}<0.01)$.

\section{Stage (iii) Feature selection (FS) and machine learning methods}

144 Stage (iii) is to select the optimum genes to ensure the final set of genes selected is with higher 145 standard and high quality in term of genetic evaluation. This is also to fully utilize the 146 measurements of different machine learning methods (supervised and unsupervised) by 147 collaborating them in selecting the significant genes. The machine learning methods chosen in this study are based on the literature review done which obtained good result in the related studies [26$14933]$.

Seven supervised machine learning FS methods and an unsupervised were used in this study. Among the seven supervised machine learning FS methods, four filter approaches which are Pearson Correlation Coefficient(PCC), Relief-F Feature Selection (Relief-F), Correlation Feature Selection (CFS) and Information Gain (IG) are used in this study for their simplicity and high in good succession in performing FS. The features (genes) that selected by the filter approach are based on the relevance of the genes with the surrounding data [34,35]. Besides that, one wrapper approach, Sequential Forward Selection (SFS) was carried out in this study as it acts as a searching 
157 algorithm that could find a subset of genes that is maximum according to the objective function

158 (classification performance) [34,35]. Furthermore, this study also applied two embedded

159 approaches which are Support Vector Machine-based Recursive Feature Elimination (SVM-RFE)

160 and Random Forest (RF) which embed variable selection as part of their learning process and

161 evaluate them according to the classification result of specific machine learning method [34,35].

162 Hierarchical Clustering (HC) was applied as the unsupervised model in this study for its ability to 163 select the genes without the knowledge of the class labels [34].

164 As the supervised machine learning methods involves the classification according to the class

165 labels, the normal samples were added back at this stage (ii) so that the "learning procedures" of

166 the machine learning can be completed.

167 The machine learning approaches applied in this study are more on exploratory models which the

168 performances of the machine learning methods are not being emphasize here. The main objective

169 of this stage is to obtain the optimum genes that commonly selected using different machine

170 learning methods, regardless of the differences in the algorithm used.

171 The results (selected genes) of different FS and machine learning will be combined and converted

172 in the scoring matrix. Scores will be determined and counted by the frequency of the genes that 173 was being selected by various FS and machine learning methods.

175 Functional Pathway Analysis

176 Gene Set Enrichment Analysis (GSEA)

177 GSEA (http://software.broadinstitute.org/gsea/index.jsp) [36,37] computationally evaluates the 178 statistical significance of a priori defined set of genes with their biological states (i.e, phenotypes).

179 All the genes in the datasets are ranked according to their differential expression between 
180 phenotype groups. In this study, normal tissue samples are also added into the dataset to enable 181 the GSEA to calculate the Enrichment Scores $(E S)$ between the phenotypes. A computational 182 annotated gene set (C4) that consists of large collections of cancer-orientated microarray data is 183 provided by Molecular Signature Database (MSigDB) and linked to GSEA in order to calculate the $E S$ on our selected set of genes. $E S$ is computed for every set of genes by going through the rank list from the top. A gene set will have a higher $E S$ if the encountered gene in the gene input list is a member of the annotated gene set. A gene set is said to be significant if the normalized enrichment scores $(N E S)$ is high and its corresponding false discovery rate $(F D R)$ is low. In this study, $F D R$ value of $<0.25$ was set as the threshold to consider the significance of the gene enriched. Furthermore, pathway network could be visualized through Cytoscape [38] software based on the GSEA results.

\section{Result}

192

193

194

195

196

197

198

199

200

201

\section{Stage (i): Gene Expression Analysis of Individual Dataset}

LIMMA was used to perform the analysis in order to select out the top 10,000 differentially expressed genes from each of the individual dataset (Results showed as in Appendix 1).

LIMMA tests the average difference in log expression levels of two groups per gene by using moderated t-test. Therefore, genes selected by LIMMA are moderately different with average differential values, rather than extremely different.

\section{Stage (ii): Meta-Analysis of Multiple Dataset}

In the intersection process, 117 intersected genes among four cervical cancer datasets were identified. All cervical cancer samples from four datasets (total of 142 samples) were combined to 
202 form a meta-dataset with these 117 intersected genes. The meta-dataset is attached as in Appendix 2032.

204 Next, the analysis of the 117 genes by RankProd identified 32 upregulated genes $(\mathrm{FC}>1$, pfp $<$ $2050.01)$ and 33 down regulated genes $(\mathrm{FC}<1$, pfp $<0.01)$, with p-value $<0.05$ and $F D R$ of 0.05 as 206 the cutoff points.

207 RankProd estimated the FDR for each gene and ranked the gene according to the value that has 208 equal or smaller p-value in the whole list of genes (estimated percentage of false predictions). As 209 the product of RankProd is affected more by extreme expression values, genes that are extremely 210 expressed in at least one sample in the dataset tends to be selected. Table 2 and Table 3 show the 211 results of RankProd analysis.

Table 2 Results of RankProd analysis- 32 Upregulated genes.

Table 3 Results of RankProd analysis- 33 Downregulated genes.

215 *Notes: Description of Table 2 and Table 3: gene.index-index of genes; RP/Rsum-computed Rank 216 Product statistics; FC: (class1/class2)- average expression levels' computed fold change under 217 two conditions (upregulated class and downregulated class); pfp- estimated false positive 218 predictions value of the genes; and P-value-estimated p-value of each gene.

\section{Stage (iii): Feature Selection and Machine Learning Methods}

To find the optimum set of genes, eight FS and machine learning methods namely PCC, Relief-F, CFS, IG, SFS, SVM-RFE, RF and HC, were carried out using the set of genes resulting from the stage (ii) of meta-analysis.

224 For $\mathrm{HC}$ analysis, the expression patterns of the 32 upregulated genes are shown in the heatmap

225 and were further sub-clustered by cutting tree at the maximum heights of 1.5 of the row cluster.

226 As a result, a cluster group that contained 20 genes was found to be most correlated to each other 
227 (Figure 2(a)). The same rule was applied to the 33 downregulated genes. The most correlated group

228 that contained 26 genes was also identified (Figure 2 (b)). The genes that were selected in the

229

230

231

232

233

234

235

236

237

238

239

240

241

242

243

244

245

246

247

248

249

250

251

252

253

254

255

256

257

cluster that had the highest scores are presented in Table 4 and Table 5 respectively.

Figure 2 Hierarchical clustering of the selected genes. (a) Hierarchical clustering of the 32 upregulated genes. (b) Hierarchical clustering of the 33 downregulated genes. In the figures, each gene is represented by the rows and the samples are represented by the columns. The dendrogram at the side indicates the relation between the pattern of the gene expression while the top-dendrogram indicates the relation between the samples used. The level of expression of the genes, relative to the mean of the gene across all samples, is indicated by the colour key, with the green representing the higher expression of the genes. The colour bar on the left side represents the cluster of the genes after they have been cut at 1.5 of the height of the tree so that the clustering of the genes is seen more clearly. The colour of the bar is indicated by the colour key similarly.

As for the scoring measures, the final score obtained by each of the genes is the frequency it was selected by the listed FS and machine learning methods (1 score for selected, 0 score for not selected). The higher the score of a gene, the more frequently the gene was selected by the different FS methods, and the higher the potential for the gene to be a gene marker of cervical cancer. Table 4 and Table 5 show the set of genes selected by the FS methods. The up- and downregulated genes with score $\geq 6$ (full score $=8$, threshold $=75 \%$ ) were identified and selected. In total, 21 gene expression set consisted of 9 upregulated genes and 12 downregulated genes were selected.

Table 4 Ranking of each gene (upregulated) using proposed FS methods.

*The 9 upregulated genes selected by most $(\geq 6)$ of the methods are CNKSR2, PEG3, SPATA6, SPON1, BTD, AK026407, RPLP2, TCF3 and TMEM115.

Table 5 Ranking of each gene (downregulated) using proposed FS methods.

*The 12 downregulated genes selected by most $(\geq 6)$ of the methods are RPL15, HIGDIA, ARL6IP5, PRDX3, COPB2, CNIH1, PSMD6, LSM3, PDHB, SLC5A3, PTS and ASF1B. As gene HIGDIA is selected twice with different ID REF, it only considered once here. 
259 GSEA was carried out on the selected 21-gene expression set for functional analysis to measure

260 the statistical significance of their biological phenotypes. In our study, we are assessing the

261 enrichment of the selected 9-upregulated and 12-downregulated genes on their natural phenotypes,

262 which are tumour and non-tumour. Therefore, samples of normal cells that were filtered at the

263 beginning of the study were added back to complete the study. A computational gene set (C4)

264 consisted of large collections of cancer-orientated microarray data was downloaded from MSigDB

265 to calculate the enrichment scores of the 9-upregulated genes and 12-downregulated genes among

266 the annotated gene sets of C4. We evaluated the normalized enrichment scores (NES) and the

267 corresponding false discovery rate $(F D R)$ of each gene on all of the samples used in this study. In

268 this study, a gene will be rejected when the FDR q-value is more than 0.25 (not significant). As

$269 N E S$ values are dependent on the permutation method and size of the expression dataset, there is

270 no standard threshold for this value in analysing the gene. A gene could match multiple sets of

271 gene sets in the database, hence we selected the highest $N E S$ values for each respective gene as

272 shown in Table 6 and Table 7. The details of GSEA report on the annotation of the 21-gene

273 expression set with the description of each gene sets are attached in Appendix 3.

274 Table 6 Results of GSEA analysis using the 9 upregulated-genes.

275 *There was no matching of gene AK026407, TCF3 and TMEM115 with the MSigDB.

276 Table 7 Results of GSEA analysis using the 12 downregulated-genes.

277 *There was no matching of gene ARL6IP5, CNIH1 and PTS with the MSigDB.

278 Among the 9 upregulated genes, 6 genes were matched with the cancerous gene set collections, as

279 shown in Table 6. Notably, PEG3, SPON1, BTD and RPLP2 passed the defined threshold of FDR

$280<0.25$, indicating the potential of these genes in showing their significances in cervical cancer. As

281 there was very limited information regarding genes $A K 026407, T C F 3$ and $T M E M 115$, there are no 
282 matching genes with the MSigDB. Besides that, 9 downregulated genes were matched with the C4

283 gene sets in MSigDB (Table 7). This showed that the 9 genes were enriched and highly related to

284 cancers. Among enriched genes, five downregulated genes, PRDX3, COPB2, LSM3, SLC5A3 and

$285 A S 1 B$, passed the default threshold with $F D R<0.25$. These also provided some attraction points

286 for the selected downregulated genes in proving their significances in cervical cancer. However,

287 there are no matching of the genes ARL6IP5, CNIH1 and PTS with the MSigDB due to the low

288 information found regarding these genes.

289 Figure 3 and Figure 4 show the pathway network constructed according to the GSEA report

290 generated in Appendix 3. The threshold that used in the pathway analysis was set to $F D R<0.25$ in

291 order to standardize with GSEA. Each of the nodes in the networks represented the gene sets that

292 the genes involved in. The genes that showed enrichment with the gene sets were indicated in the

293 colour nodes while the line connecting the nodes are the pathways that the enriched genes found 294 in.

295

296

Figure 3 Pathway network of the upregulated genes.

297

298

Figure 4 Pathway network of the downregulated genes.

299

In Figure3, the upregulated genes $P E G 3, S P O N 1, B T D$ and $R P L P 2$ were shown to be related with the pathway of gene expression, disease or cancer, and protein metabolism. Similarly, as shown in

Figure 4, downregulated genes $P R D X 3, C O P B 2, L S M 3$, SLC5A3 and $A S F 1 B$ were involving in 302 the gene expression, disease or cancer, protein metabolism and cell cycle pathways.

\section{Discussion}




\section{Integrative approach of meta-analysis and machine learning}

305 The aim of this study was to identify a set of more precise, accurate and reliable potential cervical

306

307

308

309

310

311

312

313

314

315

316

317

318

319

320

321

322

323

324

325

cancer gene markers. Generally, there are three stages of analysis in this study: (i) gene expression analysis of individual dataset; (ii) meta-analysis of multiple datasets and (iii) FS and machine learning analysis.

At the first stage, individual analysis of each cervical cancer microarray gene expression dataset was carried out using LIMMA package in R. In LIMMA, the average difference of log expression levels between two groups of information provided for each gene was calculated using moderated t-statistic, to ensure that the final list of genes produced consists of genes that are consistently different between the groups. In other words, LIMMA avoids choosing the extremely different genes in the datasets. In this study, Benjamini and Hochberg's method in controlling the FDR value was used as the default adjustment method of the adjusted p-value. The adjusted p-value is set to be $<0.05$ in expecting the proportion of the false discoveries in the selected gene group to be less than $5 \%$.

In the meta-analysis stage, RankProd package was chosen for use for two reasons; to analyse the combination of datasets from different origins and select genes with higher biological significances. RankProd package is able to avoid errors that are caused from batch and platform differences in combining expression values of various studies, by performing ranking of the genes by their differential expression [39]. RankProd estimated the gene ranking by randomly permutating the list of genes. False discovery rates $(F D R)$ for the whole list of genes which are equal or smaller than the p-value (known as false positive prediction, pfp) were calculated by this package and the genes were ranked accordingly. 
326 The selection of genes in the RankProd analysis in the stage (ii) was based on the criteria of FC $>1$

327 (upregulated genes) or $\mathrm{FC}<1$ (downregulated genes). In log expression level, a gene is said to be

328 significantly upregulated when the FC expression is $>1$ while it is significantly downregulated when the

$329 \mathrm{FC}<1$. An FC with value of two simply brings the meaning that the particular genes expressed twice more

330 than the genes in the original control. Besides that, php value is set to $<0.01$ in order to select the genes

331 that sited on the top $1 \%$ of the truly significant genes among all the genes to be studied.

332 Following meta-analysis, 32 most significantly up-regulated and 33 down-regulated genes were 333 selected.

334 To further narrow down the range of the genes selected and also to fully adopt the benefits from 335 the statistical and also the machine-based analysis method, four filter approaches (PCC, Relief-F, 336 CFS and IG), a wrapper approach (SFS), two embedded approach (SVM-RFE and RF) and an

337

338

339

340

341

342 unsupervised approach of $\mathrm{HC}$ were carried out. As the algorithms in selecting genes by each method were different, the resultant genes selected by each method varies. In this study, most of the parameters set are based on the default values or the minimum values required as the focus is on the most significant genes that selected by the machine learning method and not the predictive performances of the machine learning methods).

We ensured the accuracy of our results by creating a scoring system to calculate the score of each gene. The threshold for the scoring system was set to $75 \%$, where only the genes with score $\geq 6$ (out of 8) would be selected. In total, 21-gene expression set which consisted of 9 upregulated genes and 12 downregulated genes were selected. The upregulated genes that were most commonly selected by the stated FS methods were PEG3, SPON1, BTD, RPLP2, CNKSR2, SPATA6, AK026407, TCF3 and TMEM115 while the FS-commonly-selected-downregulated- 
348 349

350

351

352

353

354

355

356

357

358

359

360

361

362

363

364

365

366

367

368

genes were PRDX3, COPB2, LSM3, SLC5A3, ASF1B, RPL15, HIGD1A, ARL6IP5, CNIH1, PSMD6, PDHB, and PTS.

\section{Functional Pathway Analysis- GSEA}

According to the annotation of the 21 genes ( 9 upregulated genes and 12 downregulated genes) to the C4 cancerous gene set collection in MSigDB GSEA, it showed that six upregulated genes ((CNKSR2, PEG3, SPATA6, SPON1, BTD and TCF3) and nine downregulated genes (RPL15, HIGD1A, PRDX3, COPB2, PSMD6, LSM3, PDHB, SLC5A3 and ASF1B) were enriched with the computational cancerous gene set. Particularly, 4 upregulated genes (SPON1, PEG3, RPLP2 and $B T D)$ and 5 downregulate genes (PRDX3, COPB2, LSM3, SLCA3 and ASF1B) showed significant enrichment to the cancerous modules and cancerous genes neighbourhood gene sets with the $F D R<$ 0.25. This indicates that these 9 genes were highly correlated with the formation of cancer and were selected as the 9-potential-gene-expression signature in this study.

The pathway network (Figure 3 and Figure 4) were constructed using the GSEA report that attached as in Appendix 3. The networks shown were based on the correlation between the gene sets. Similar with GSEA, the threshold was set to $F D R<0.25$ in this analysis. By comparing the map constructed and the GSEA result, it can be clearly seen that both results are supporting each other. The genes that showed significant enrichment with the $\mathrm{C} 4$ gene sets were shown and constructed in the network too. Moreover, the genes involved in the pathways of gene expression, disease or cancer, protein metabolism and cell cycle (Figure 3 and Figure 4). This further strengthened the role of the selected genes to be the 9-potential signature in relation with cervical cancer development. 
369 The 9-potential signature will be discussed and supported by the previous studies done in the

370 following section.

371 Upregulated genes are the genes that are known to be overexpressed during the gene regulation

372 stage, causing the development of the tumour or potential cancerous cell. The most significant

373 upregulated genes set that formed after the GSEA analysis are PEG3, SPON1, BTD and RPLP2.

374 Table 8 shows the function of the upregulated genes selected, together with the related diseases

375 and description.

376 Table 8 Function, related diseases and description of the most significant genes

377 (Upregulated).

378 Despite the focus of gene expression research in cancers are towards the upregulated genes, the 379 role of downregulated genes should not be ignored. Lu et al. [56] found that in general, tumours 380 contained more downregulated miRNAs compared with the normal tissues, leading them to 381 hypothesize that down-regulated expression of some miRNAs may play a key role in the 382 development of tumours and that gene downregulation is as important an aspect to be studied as 383 up-regulation.

384 The most significant identified downregulated genes in cervical cancer in this study are $P R D X 3$, 385 COPB2, LSM3, SLC5A3 and $A S F 1 B$. The biological functions, related diseases and description 386 are shown in Table 9.

387 Table 9 Function, related diseases and description of the most significant genes 388 (Downregulated).

389 Our integrated approach of meta-analysis and machine-learning method successfully identified the 390 potential genetic markers in cervical cancer, along with the evidence provided from the GSEA 391 results and the previous study done. The identified genes can be considered as potential gene 
392 signatures in cervical cancer. However, further evaluation using other experimental methods are

393 needed in order to validate the significance of the 9-potential-gene expression cervical cancer 394 signatures.

\section{Conclusion}

396 In this study, we proposed an integrative machine learning analysis of multiple gene expression 397 profiles in cervical cancer. This integrative analysis is divided into three stages which are (i) gene 398 expression analysis of individual dataset; (ii) meta-analysis of multiple datasets and (iii) FS \& 399 machine learning analysis with PCC, Relief-F, CFS, IG, SFS, SVM-RFE, RF and HC. As a result, 4009 upregulated genes and 12 downregulated genes, were selected through the three-step analysis. 401 The result of the functional pathway analysis in GSEA showed the significant enrichment in 9402 potential-gene-expression signature namely PEG3, SPON1, BTD, RPLP2 (as upregulated genes) 403 and PRDX3, COPB2, LSM3, SLC5A3, ASF1B (as downregulated genes). More experiments are 404 needed to confirm the significance of the selected 9-potential-gene-expression signature in cervical 405 cancer.

\section{Reference}

407 1. Cervical cancer statistics. World Cancer Research Fund International. Available at http://www.wcrf.org/int/cancer-facts-figures/data-specific-cancers/cervical-cancer-

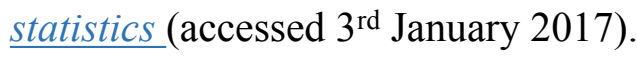

2. World Health Organization. (2016). World Health Statistics 2016: Monitoring Health for the SDGs Sustainable Development Goals. World Health Organization. 
412

413

414

415

416

417

418

419

420

421

422

423

424

425

426

427

428

429

430

431

432

433
3. AbM A, Nor Saleh I, and Noor Hashima A. 2016. Malaysian National Cancer Registry Report 2007-2011. Malaysia Cancer Statistics, Data and Figure. National Cancer Institute, Ministry of Health, Putrajaya, Malaysia

4. Plummer M, Herrero R, Franceschi S, Meijer CJ, Snijders P, Bosch FX, de Sanjosé S, and Muñoz N. 2003. Smoking and cervical cancer: pooled analysis of the IARC multi-centric case-control study. Cancer Causes and Control 14:805-814.

5. Ames BN, and Gold LS. 1997. The causes and prevention of cancer: gaining perspective. Environmental Health Perspectives 105:865.

6. Lee SA, Kang D, Seo SS, Jeong JK, Yoo KY, Jeon YT, Kim JW, Park NH, Kang SB, and Lee HP. 2003. Multiple HPV infection in cervical cancer screened by HPVDNAChip ${ }^{\mathrm{TM}}$. Cancer letters 198:187-192.

7. Hu X, Schwarz JK, Lewis JS, Huettner PC, Rader JS, Deasy JO, Grigsby PW, and Wang X. 2010. A microRNA expression signature for cervical cancer prognosis. Cancer research 70:1441-1448.

8. Aziz NAA, Mokhtar NM, Harun R, Mollah MMH, Rose IM, Sagap I, Tamil AM, Ngah WZW, and Jamal R. 2016. A 19-Gene expression signature as a predictor of survival in colorectal cancer. BMC medical genomics 9:58.

9. Warnat P, Eils R, and Brors B. 2005. Cross-platform analysis of cancer microarray data improves gene expression based classification of phenotypes. BMC bioinformatics 6:265.

10. Brazma A, Hingamp P, Quackenbush J, Sherlock G, Spellman P, Stoeckert C, Aach J, Ansorge W, Ball CA, and Causton HC. 2001. Minimum information about a microarray experiment (MIAME) — toward standards for microarray data. Nature genetics 29:365-371. 
434

435

436

437

438

439

440

441

442

443

444

445

446

447

448

449

450

451

452

453

454

455

456
11. Alles MC, Gardiner-Garden M, Nott DJ, Wang Y, Foekens JA, Sutherland RL, Musgrove EA, and Ormandy CJ. 2009. Meta-analysis and gene set enrichment relative to er status reveal elevated activity of MYC and E2F in the "basal" breast cancer subgroup. PloS one 4:e4710.

12. Chow, Y. P., Alias, H., \& Jamal, R. (2017). Meta-analysis of gene expression in relapsed childhood B-acute lymphoblastic leukemia. BMC cancer, 17(1), 120.

13. Dong, H., Hong, S., Xu, X., Xiao, Y., Jin, L., \& Xiong, M. (2010, May). Meta-analysis and Network Analysis of Five Ovarian Cancer Gene Expression Dataset. In Computational Science and Optimization (CSO), 2010 Third International Joint Conference on (Vol. 1, pp. 242-246). IEEE.

14. Li, W. X., Dai, S. X., Wang, Q., Guo, Y. C., Hong, Y., Zheng, J. J., ... \& Huang, J. F. (2016). Integrated analysis of ischemic stroke datasets revealed sex and age difference in anti-stroke targets. PeerJ, 4, e2470.

15. Grützmann R, Boriss H, Ammerpohl O, Lüttges J, Kalthoff H, Schackert HK, Klöppel G, Saeger HD, and Pilarsky C. 2005. Meta-analysis of microarray data on pancreatic cancer defines a set of commonly dysregulated genes. Oncogene 24:5079-5088.

16. Liu, B., Cui, Q., Jiang, T., \& Ma, S. (2004). A combinational feature selection and ensemble neural network method for classification of gene expression data. $B M C$ bioinformatics, 5(1), 136.

17. Obayashi, T., \& Kinoshita, K. (2009). Rank of correlation coefficient as a comparable measure for biological significance of gene coexpression. DNA research, 16(5), 249-260.

18. Wang, Y., \& Makedon, F. (2004, August). Application of Relief-F feature filtering algorithm to selecting informative genes for cancer classification using microarray data. 

2004 IEEE (pp. 497-498). IEEE.

19. Díaz-Uriarte, R., \& De Andres, S. A. (2006). Gene selection and classification of microarray data using random forest. BMC bioinformatics, $7(1), 3$.

20. Noordhuis MG, Fehrmann RS, Wisman GBA, Nijhuis ER, van Zanden JJ, Moerland PD, van Themaat EVL, Volders HH, Kok M, and Klaske A. 2011. Involvement of the TGF- $\beta$ and $\beta$-catenin pathways in pelvic lymph node metastasis in early-stage cervical cancer. Clinical Cancer Research.

21. Bachtiary B, Boutros PC, Pintilie M, Shi W, Bastianutto C, Li J-H, Schwock J, Zhang W, Penn LZ, and Jurisica I. 2006. Gene expression profiling in cervical cancer: an exploration of intratumor heterogeneity. Clinical Cancer Research 12:5632-5640.

22. Scotto L, Narayan G, Nandula SV, Arias-Pulido H, Subramaniyam S, Schneider A, Kaufmann AM, Wright JD, Pothuri B, and Mansukhani M. 2008. Identification of copy number gain and overexpressed genes on chromosome arm $20 \mathrm{q}$ by an integrative genomic approach in cervical cancer: potential role in progression. Genes, Chromosomes and Cancer 47:755-765.

23. Den Boon JA, Pyeon D, Wang SS, Horswill M, Schiffman M, Sherman M, Zuna RE, Wang Z, Hewitt SM, and Pearson R. 2015. Molecular transitions from papillomavirus infection to cervical precancer and cancer: Role of stromal estrogen receptor signaling. Proceedings of the National Academy of Sciences 112:E3255-E3264.

24. Smyth GK. 2004. Linear models and empirical bayes methods for assessing differential expression in microarray experiments. Statistical applications in genetics and molecular biology $3: 1-25$. 
480

481

482

483

484

485

486

487

488

489

490

491

492

493

494

495

496

497

498

499

500

501

502
25. Breitling R, Armengaud P, Amtmann A, and Herzyk P. 2004. Rank products: a simple, yet powerful, new method to detect differentially regulated genes in replicated microarray experiments. FEBS letters 573:83-92.

26. Urbanowicz RJ, Meeker M, LaCava W, Olson RS, and Moore JH. 2017. Relief-based feature selection: introduction and review. arXiv preprint arXiv:171108421.

27. Wang Y, Tetko IV, Hall MA, Frank E, Facius A, Mayer KF, and Mewes HW. 2005. Gene selection from microarray data for cancer classification-a machine learning approach. Computational biology and chemistry 29:37-46.

28. Martín-Valdivia MT, Díaz-Galiano MC, Montejo-Raez A, and Urena-Lopez L. 2008. Using information gain to improve multi-modal information retrieval systems. Information Processing \& Management 44:1146-1158.

29. Guyon I, Weston J, Barnhill S, and Vapnik V. 2002. Gene selection for cancer classification using support vector machines. Machine learning 46:389-422.

30. Breiman L. 2001. Random forests. Machine learning 45:5-32.

31. Díaz-Uriarte R, and De Andres SA. 2006. Gene selection and classification of microarray data using random forest. BMC bioinformatics 7:3.

32. Sneath PH. 1973. The principles and practice of numerical classification. Numerical taxonomy 573.

33. Eisen MB, Spellman PT, Brown PO, and Botstein D. 1998. Cluster analysis and display of genome-wide expression patterns. Proceedings of the National Academy of Sciences 95:14863-14868.

34. Chandrashekar G, and Sahin F. 2014. A survey on feature selection methods. Computers \& Electrical Engineering 40:16-28. 
503

504

505

506

507

508

509

510

511

512

513

514

515

516

517

518

519

520

521

522

523

524

525

35. Saeys Y, Inza I, and Larrañaga P. 2007. A review of feature selection techniques in bioinformatics. bioinformatics 23:2507-2517.

36. Subramanian A, Tamayo P, Mootha VK, Mukherjee S, Ebert BL, Gillette MA, Paulovich A, Pomeroy SL, Golub TR, and Lander ES. 2005. Gene set enrichment analysis: a knowledge-based approach for interpreting genome-wide expression profiles. Proceedings of the National Academy of Sciences 102:15545-15550.

37. Mootha VK, Lindgren CM, Eriksson K-F, Subramanian A, Sihag S, Lehar J, Puigserver P, Carlsson E, Ridderstråle M, and Laurila E. 2003. PGC-1 $\alpha$-responsive genes involved in oxidative phosphorylation are coordinately downregulated in human diabetes. Nature genetics 34:267-273.

38. Shannon P, Markiel A, Ozier O, Baliga NS, Wang JT, Ramage D, Amin N, Schwikowski B, and Ideker T. 2003. Cytoscape: a software environment for integrated models of biomolecular interaction networks. Genome research 13:2498-2504.

39. Hong F, Breitling R, McEntee CW, Wittner BS, Nemhauser JL, and Chory J. 2006. RankProd: a bioconductor package for detecting differentially expressed genes in metaanalysis. Bioinformatics 22:2825-2827.

40. Nye MD, Hoyo C, Huang Z, Vidal AC, Wang F, Overcash F, Smith JS, Vasquez B, Hernandez B, and Swai B. 2013. Associations between methylation of paternally expressed gene 3 (PEG3), cervical intraepithelial neoplasia and invasive cervical cancer. PloS one 8:e56325.

41. Yamaguchi A, Taniguchi M, Hori O, Ogawa S, Tojo N, Matsuoka N, Miyake S-i, Kasai K, Sugimoto H, and Tamatani M. 2002. Peg3/Pw1 is involved in p53-mediated cell death pathway in brain ischemia/hypoxia. Journal of Biological Chemistry 277:623-629. 
526

527

528

529

530

531

532

533

534

535

536

537

538

539

540

541

542

543

544

545

546

42. Jiang X, Yu Y, Yang HW, Agar NY, Frado L, and Johnson MD. 2010. The imprinted gene PEG3 inhibits Wnt signaling and regulates glioma growth. Journal of Biological Chemistry 285:8472-8480.

43. Burstyn-Cohen T, Tzarfaty V, Frumkin A, Feinstein Y, Stoeckli E, and Klar A. 1999. FSpondin is required for accurate pathfinding of commissural axons at the floor plate. Neuron 23:233-246.

44. Pagnotta SM, Laudanna C, Pancione M, Sabatino L, Votino C, Remo A, Cerulo L, Zoppoli P, Manfrin E, and Colantuoni V. 2013. Ensemble of gene signatures identifies novel biomarkers in colorectal Cancer activated through PPAR $\gamma$ and TNF $\alpha$ signaling. PloS one 8:e72638.

45. Zhai Y, Bommer GT, Feng Y, Wiese AB, Fearon ER, and Cho KR. 2010. Loss of estrogen receptor 1 enhances cervical cancer invasion. The American journal of pathology 177:884895.

46. Faith M, and Abraham P. 2013. An update on diagnostic value of biotinidase: From liver damage to cancer: Minireview. Biomedical Research 24.

47. Huang L, Zheng M, Zhou QM, Zhang MY, Jia WH, Yun JP, and Wang HY. 2011. Identification of a gene-expression signature for predicting lymph node metastasis in patients with early stage cervical carcinoma. Cancer 117:3363-3373.

48. So AK-C, Kaur J, Kak I, Assi J, MacMillan C, Ralhan R, and Walfish PG. 2012. Biotinidase is a novel marker for papillary thyroid cancer aggressiveness. PloS one 7:e40956. 
547

548

549

550

551

552

553

554

555

556

557

558

559

560

561

562

563

564

565

566

567
49. Scheerger, and Zempleni. 2003. Expression of oncogenes depends on biotin in human small cell lung cancer cells NCI-H69. International journal for vitamin and nutrition research 73:461-467.

50. Kang U-B, Ahn Y, Lee JW, Kim Y-H, Kim J, Yu M-H, Noh D-Y, and Lee C. 2010. Differential profiling of breast cancer plasma proteome by isotope-coded affinity tagging method reveals biotinidase as a breast cancer biomarker. BMC cancer 10:114.

51. Zhang Y-Z, Zhang L-H, Gao Y, Li C-H, Jia S-Q, Liu N, Cheng F, Niu D-Y, Cho WC, and Ji J-F. 2011. Discovery and validation of prognostic markers in gastric cancer by genomewide expression profiling. World journal of gastroenterology: WJG 17:1710.

52. Sharp M, Adams S, Elvin P, Walker R, Brammar W, and Varley J. 1990. A sequence previously identified as metastasis-related encodes an acidic ribosomal phosphoprotein, P2. British journal of cancer $61: 83-88$.

53. Mao-De L, and Jing X. 2007. Ribosomal proteins and colorectal cancer. Current genomics $8: 43-49$.

54. Lu J, Getz G, Miska EA, Alvarez-Saavedra E, Lamb J, Peck D, Sweet-Cordero A, Ebert BL, Mak RH, and Ferrando AA. 2005. MicroRNA expression profiles classify human cancers. nature 435:834-838.

55. Safaeian M, Hildesheim A, Gonzalez P, Yu K, Porras C, Li Q, Rodriguez AC, Sherman ME, Schiffman M, and Wacholder S. 2012. Single nucleotide polymorphisms in the PRDX3 and RPS19 and risk of HPV persistence and cervical precancer/cancer. PloS one 7:e33619. 
568

569

570

571

572

573

574

575

576

577

578

579

580

581

582

583

584

585

586

587

588

589

590

56. Jiang Y, Sang Y, and Qiu Q. 2017. microRNA-383 mediates high glucose-induced oxidative stress and apoptosis in retinal pigment epithelial cells by repressing peroxiredoxin 3. American journal of translational research 9:2374.

57. Kim K, Yu M, Han S, Oh I, Choi Y-J, Kim S, Yoon K, Jung M, and Choe W. 2009. Expression of human peroxiredoxin isoforms in response to cervical carcinogenesis. Oncology reports 21:1391-1396.

58. Hu J-X, Gao Q, and Li L. 2013. Peroxiredoxin 3 is a novel marker for cell proliferation in cervical cancer. Biomedical reports 1:228-230.

59. Hu J, and Gao DZ. 2012. Distinction immune genes of hepatitis-induced heptatocellular carcinoma. Bioinformatics 28:3191-3194.

60. Coutinho-Camillo CM, Salaorni S, Sarkis ÁS, and Nagai MA. 2006. Differentially expressed genes in the prostate cancer cell line LNCaP after exposure to androgen and antiandrogen. Cancer genetics and cytogenetics 166:130-138.

61. Lyng H, Brøvig RS, Svendsrud DH, Holm R, Kaalhus O, Knutstad K, Oksefjell H, Sundfør K, Kristensen GB, and Stokke T. 2006. Gene expressions and copy numbers associated with metastatic phenotypes of uterine cervical cancer. BMC genomics 7:268.

62. Wright EM, and Turk E. 2004. The sodium/glucose cotransport family SLC5. Pflügers Archiv 447:510-518.

63. Database GCHG. SLC5A3 Gene(Protein Coding). GeneCards. Available at http://www.genecards.org/cgi-bin/carddisp.pl?gene $=S L C 5 A 3$ (accessed $5^{\text {th }}$ July 2017)

64. Chung YM, Kim BG, Park CS, Huh SJ, Kim J, Park JK, Cho SM, Kim BS, Kim JS, and Yoo YD. 2005. Increased expression of ICAM-3 is associated with radiation resistance in cervical cancer. International journal of cancer 117:194-201. 
591 592 593 594 595 596

\section{Supplementary Information}

603

604 605

Appendix 1- Result of LIMMA analysis

Appendix 3- GSEA analysis result

65. Narod S, Seth A, and Nam R. 2008. Fusion in the ETS gene family and prostate cancer. British journal of cancer 99:847-851.

66. Le S, Davis C, Konopka JB, and Sternglanz R. 1997. Two new S-phase-specific genes from Saccharomyces cerevisiae. Yeast 13:1029-1042.

67. Corpet A, De Koning L, Toedling J, Savignoni A, Berger F, Lemaître C, O'sullivan RJ, Karlseder J, Barillot E, and Asselain B. 2011. Asflb, the necessary Asf1 isoform for proliferation, is predictive of outcome in breast cancer. The EMBO journal 30:480-493.

68. Rosty C, Sheffer M, Tsafrir D, Stransky N, Tsafrir I, Peter M, de Cremoux P, de La Rochefordière A, Salmon R, and Dorval T. 2005. Identification of a proliferation gene cluster associated with HPV E6/E7 expression level and viral DNA load in invasive cervical carcinoma. Oncogene 24:7094-7104.

Appendix 2- Gene expression dataset of combined dataset 


\section{Figure 1 (on next page)}

Framework for the proposed integrative approach of meta-analysis and machine learning in gene expression profiling of cervical cancer.

*DE- differential expression value 


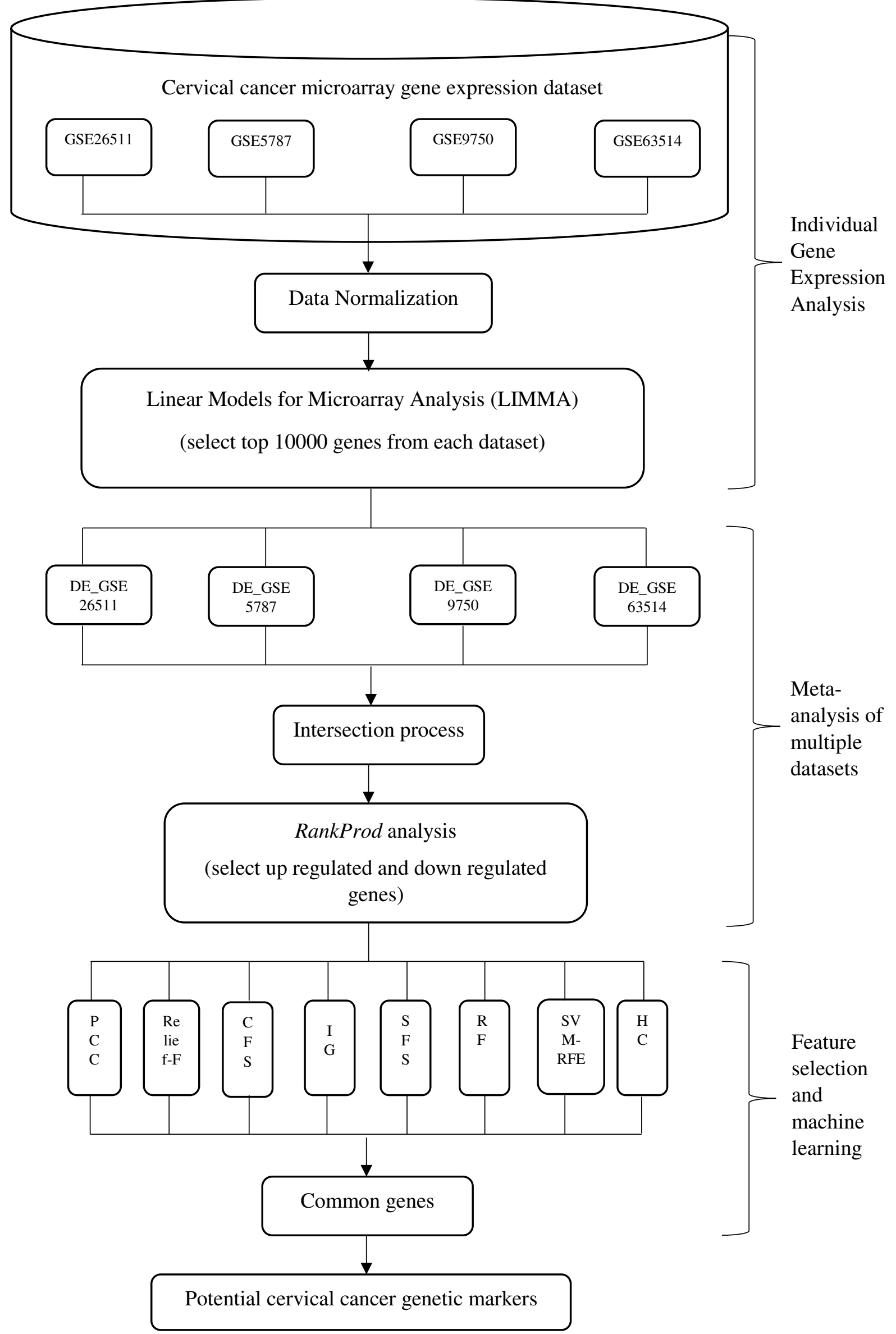




\section{Figure 2}

Hierarchical clustering of the selected genes. (a) Hierarchical clustering of the 32 upregulated genes. (b) Hierarchical clustering of the 33 downregulated genes.

In the figures, each gene is represented by the rows and the samples are represented by the columns. The dendogram at the side indicates the relation between the pattern of the gene expression while the top-dendogram indicates the relation between the samples used. The level of expression of the genes, relative to the mean of the gene across all samples, is indicated by the color key, with the green representing the higher expression of the genes. The color bar on the left side represents the cluster of the genes after they have been cut at 1.5 of the height of the tree so that the clustering of the genes is seen more clearly. The color of the bar is indicated by the color key similarly.

(a)
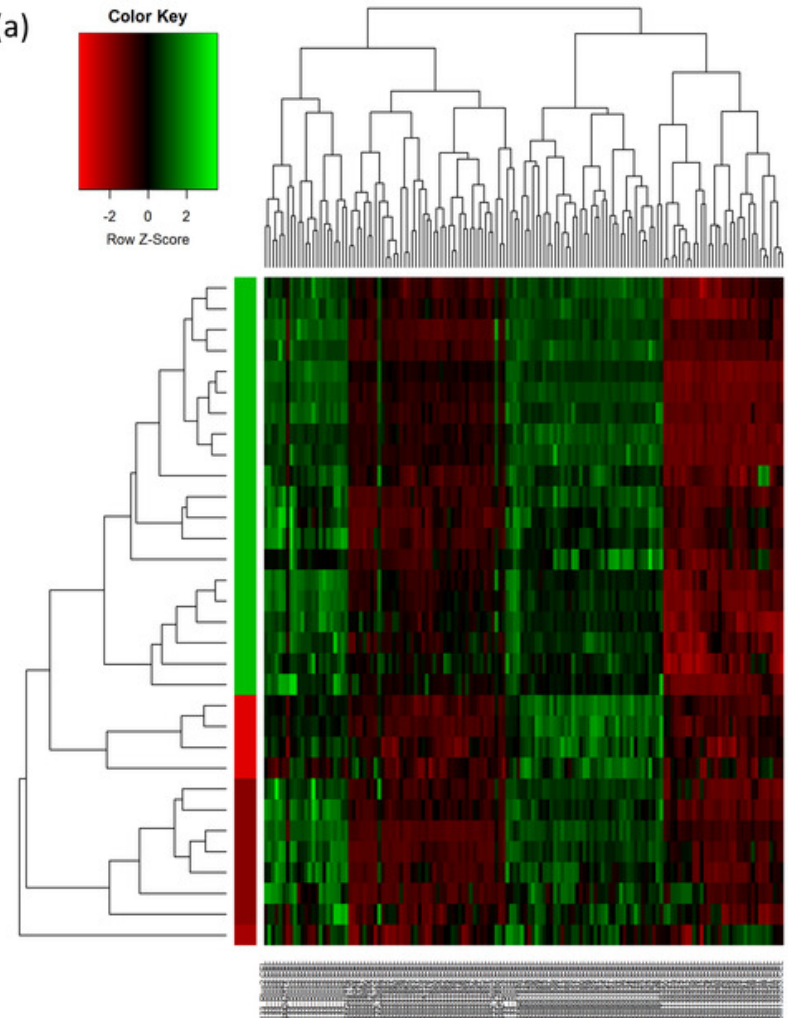

(b)
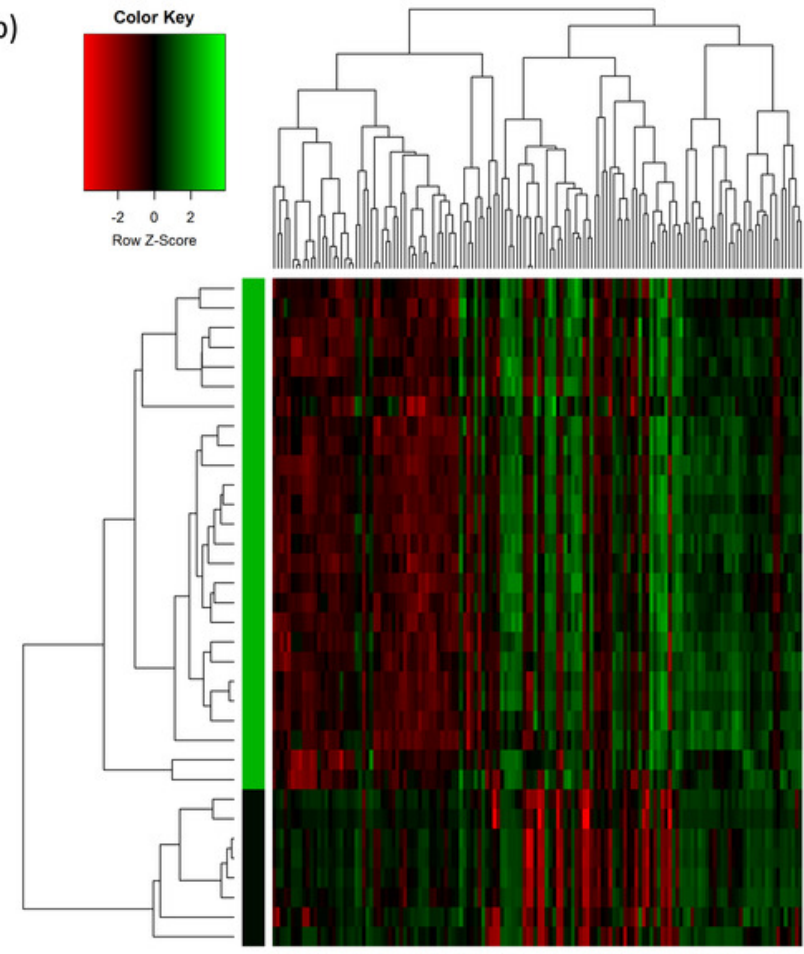

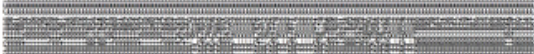


Figure 3

Pathway network of the upregulated genes.
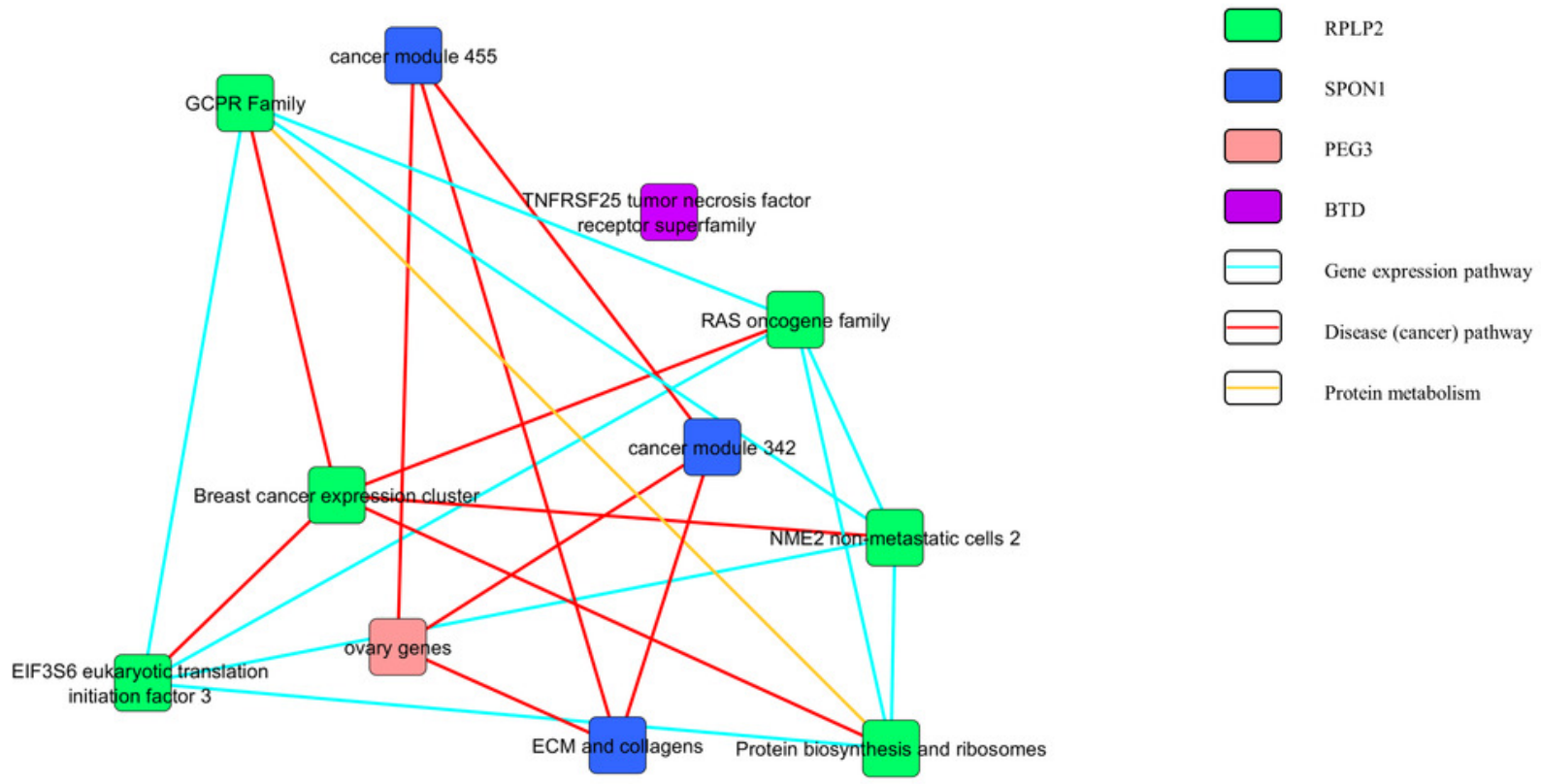


\section{Figure 4}

\section{Pathway network of the downregulated genes.}
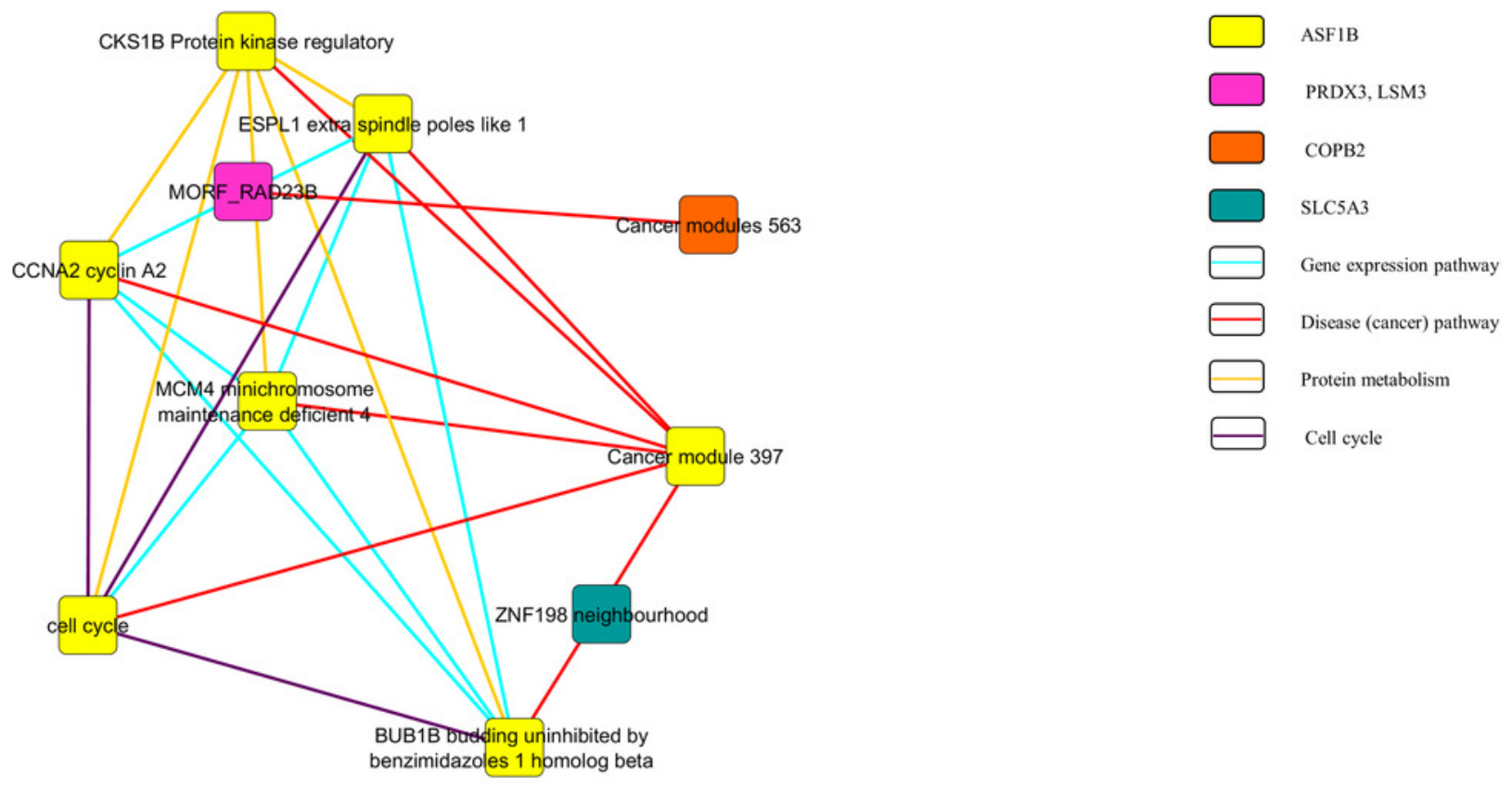


\section{Table 1 (on next page)}

Details of the four microarray datasets used in this research. 
1 Details of the four microarray datasets used in this research.

\begin{tabular}{|c|c|c|c|c|}
\hline Study & Platform & Samples & Genes & Variables \\
\hline $\begin{array}{l}\text { Noordhuis MG et } \\
\text { al (GSE26511) } \\
{[20]}\end{array}$ & $\begin{array}{l}\text { HG- } \\
\text { U133_Plus_2 }\end{array}$ & 39 & 54675 & $\begin{array}{l}\text { Lymph node status: negative, } \\
\text { positive }\{19\}\end{array}$ \\
\hline $\begin{array}{l}\text { Bachtiary B et al } \\
(\text { GSE5787) [21] }\end{array}$ & $\begin{array}{l}\text { HG- } \\
\text { U133 Plus } 2\end{array}$ & 33 & 54675 & $\begin{array}{l}\text { Biopsy: } 1\{5\}, 2\{6\}, 3\{7\}, 4\{5\}, 5\{5\}, \\
6\{3\}, 7\{2\}\end{array}$ \\
\hline $\begin{array}{l}\text { Scotto L et al } \\
\text { (GSE9750) [22] }\end{array}$ & HG-U133A & 61 & 22283 & $\begin{array}{l}\text { tissue: normal }\{24\}, \text { cell line }\{5\} \text {, } \\
\text { cancer }\{28\}\end{array}$ \\
\hline $\begin{array}{l}\text { den Boon JA et al } \\
\text { (GSE63514) [23] }\end{array}$ & $\begin{array}{l}\text { HG- } \\
\text { U133_Plus_2 }\end{array}$ & 130 & 54675 & $\begin{array}{l}\text { tissue: normal }\{24\}, \text { CIN1 lesions }\{14\} \text {, } \\
\text { CIN2 lesions }\{22\}, \text { CIN } 3 \text { lesions }\{40\} \text {, } \\
\text { cancer }\{28\}\end{array}$ \\
\hline
\end{tabular}

2 
Table 2 (on next page)

Results of RankProd analysis- 32 Upregulated genes. 


\section{Results of RankProd analysis- 32 Upregulated genes.}

\begin{tabular}{|c|c|c|c|c|c|c|}
\hline ID_REF & Identifier & gene.index & RP/Rsum & FC:(class1/class2) & pfp & P.value \\
\hline 206731 at & CNKSR2 & 102 & 2.697 & 1.13 & $7.77 \mathrm{E}-155$ & $6.64 \mathrm{E}-157$ \\
\hline 209243 s_at & PEG3 & 107 & 2.846 & 1.13 & $1.38 \mathrm{E}-149$ & $2.36 \mathrm{E}-151$ \\
\hline 210549 s at & CCL23 & 110 & 4.156 & 1.19 & $3.15 \mathrm{E}-114$ & $8.08 \mathrm{E}-116$ \\
\hline 216108 at & LOC105373738 & 22 & 4.363 & 1.22 & $3.41 \mathrm{E}-110$ & $1.17 \mathrm{E}-111$ \\
\hline 220298 _s_at & SPATA6 & 37 & 6.35 & 1.29 & $6.39 \mathrm{E}-81$ & $2.73 \mathrm{E}-82$ \\
\hline 212797 at & SORT1 & 20 & 6.371 & 1.33 & $9.09 \mathrm{E}-81$ & $4.66 \mathrm{E}-82$ \\
\hline 207996 s at & LDLRAD4 & 71 & 10.32 & 1.66 & $1.72 \mathrm{E}-49$ & $1.03 \mathrm{E}-50$ \\
\hline 208762 at & SUMO1 & 59 & 11.02 & 1.66 & $8.37 \mathrm{E}-46$ & $5.72 \mathrm{E}-47$ \\
\hline 207257 at & EPO & 84 & 12.25 & 1.48 & $4.26 \mathrm{E}-40$ & $3.28 \mathrm{E}-41$ \\
\hline 202035 s at & SFRP1 & 73 & 12.53 & 1.50 & $5.99 \mathrm{E}-39$ & $5.12 \mathrm{E}-40$ \\
\hline 204672_s_at & ANKRD6 & 86 & 13.23 & 1.57 & $3.28 \mathrm{E}-36$ & $3.09 \mathrm{E}-37$ \\
\hline 220994 s_at & STXBP6 & 62 & 13.62 & 1.57 & $9.11 \mathrm{E}-35$ & $9.34 \mathrm{E}-36$ \\
\hline 213652 at & PCSK5 & 88 & 14.12 & 1.67 & $4.76 \mathrm{E}-33$ & $5.29 \mathrm{E}-34$ \\
\hline 213994_s_at & SPON1 & 50 & 14.35 & 1.61 & $2.72 \mathrm{E}-32$ & $3.25 \mathrm{E}-33$ \\
\hline 221606 s at & HMGN5 & 35 & 15.39 & 1.68 & $5.13 \mathrm{E}-29$ & $6.57 \mathrm{E}-30$ \\
\hline 203440 at & CDH2 & 38 & 15.74 & 1,65 & $5.24 \mathrm{E}-28$ & $7.17 \mathrm{E}-29$ \\
\hline 207046 at & HIST2H4B & 33 & 16.79 & 1.66 & $3.64 \mathrm{E}-25$ & $5.29 \mathrm{E}-26$ \\
\hline 211865 s at & FZR1 & 99 & 19.24 & 1.69 & $1.47 \mathrm{E}-19$ & $2.26 \mathrm{E}-20$ \\
\hline 215401 at & AU147698 & 17 & 19.79 & 1.74 & $1.72 \mathrm{E}-18$ & $2.79 \mathrm{E}-19$ \\
\hline 213068 at & DPT & 4 & 20.42 & 1.75 & $2.48 \mathrm{E}-17$ & $4.24 \mathrm{E}-18$ \\
\hline 214117 s_at & BTD & 34 & 22.69 & 1.80 & $1.28 \mathrm{E}-13$ & $2.30 \mathrm{E}-14$ \\
\hline 34187 at & AK026407 & 100 & 23.65 & 1.83 & $2.78 \mathrm{E}-12$ & $5.24 \mathrm{E}-13$ \\
\hline 213611 at & AQP5 & 82 & 25.09 & 1.86 & $1.82 \mathrm{E}-10$ & $3.58 \mathrm{E}-11$ \\
\hline 209465 x_at & PTN & 53 & 26.18 & 2.00 & $3.00 \mathrm{E}-09$ & $6.16 \mathrm{E}-10$ \\
\hline 208606 s_at & WNT4 & 13 & 27.42 & 1.92 & $5.31 \mathrm{E}-08$ & $1.14 \mathrm{E}-08$ \\
\hline 211814 s at & CCNE2 & 52 & 33.28 & 2.00 & 0.001144 & 0.0002542 \\
\hline 208790_s_at & PTRF & 81 & 33.49 & 2.00 & 0.00144 & 0.0003322 \\
\hline 200908 s at & RPLP2 & 40 & 33.97 & 2.04 & 0.002479 & 0.0005933 \\
\hline 219795 at & SLC6A14 & 57 & 34.09 & 2.22 & 0.002761 & 0.0006842 \\
\hline 205730_s_at & ABLIM3 & 64 & 35.48 & 2.05 & 0.01187 & 0.003044 \\
\hline 202648 at & TCF3 & 32 & 37.13 & 2.10 & 0.05047 & 0.01337 \\
\hline 216267 s at & TMEM115 & 95 & 37.72 & 2.07 & 0.07745 & 0.02118 \\
\hline
\end{tabular}




\section{Table 3(on next page)}

Results of RankProd analysis- 33 Downregulated genes.

*Notes: Description of Table 2 and Table 3: gene.index-index of genes; RP/Rsum- computed Rank Product statistics; FC: (class1/class2)- average expression levels' computed fold change under two conditions (upregulated class and downregulated class); pfp-estimated false positive predictions (pfp) value of the genes; and P.value- estimated p-value of each gene. 
1 Results of RankProd analysis- 33 Downregulated genes.

\begin{tabular}{|c|c|c|c|c|c|c|}
\hline ID_REF & Identifier & gene.index & RP/Rsum & FC:(class1/class2) & pfp & P.value \\
\hline 221475 _s_at & RPL15 & 104 & 3.889 & 0.67 & $7.27 \mathrm{E}-120$ & $1.24 \mathrm{E}-121$ \\
\hline 203535 at & S100A9 & 103 & 4.437 & 0.71 & $1.20 \mathrm{E}-108$ & $3.09 \mathrm{E}-110$ \\
\hline $209719 \times$ at & SERPINB3 & 3 & 6.49 & 0.46 & $2.94 \mathrm{E}-79$ & $1.00 \mathrm{E}-80$ \\
\hline 200074 _s_at & GUK1 & 55 & 7.095 & 0.45 & $4.17 \mathrm{E}-73$ & $1.78 \mathrm{E}-74$ \\
\hline 209351 at & KRT14 & 26 & 7.505 & 0.393 & $2.33 \mathrm{E}-69$ & $1.20 \mathrm{E}-70$ \\
\hline 201097 s at & ARF4 & 11 & 8.908 & 0.32 & $2.43 \mathrm{E}-58$ & $1.46 \mathrm{E}-59$ \\
\hline 217845 _x_at & HIGD1A & 2 & 10.75 & 0.247 & $3.25 \mathrm{E}-47$ & $2.22 \mathrm{E}-48$ \\
\hline $210413 \times$ at & SERPINB4 & 7 & 10.93 & 0.27 & $2.59 \mathrm{E}-46$ & $1.99 \mathrm{E}-47$ \\
\hline 210835 s at & CTBP2 & 77 & 12.68 & 0.17 & $2.39 \mathrm{E}-38$ & $2.05 \mathrm{E}-39$ \\
\hline 209720_s_at & SERPINB3 & 1 & 13.56 & 0.13 & $5.96 \mathrm{E}-35$ & $5.60 \mathrm{E}-36$ \\
\hline 200761 s at & ARL6IP5 & 65 & 13.75 & 0.13 & $2.67 \mathrm{E}-34$ & $2.74 \mathrm{E}-35$ \\
\hline 201619 at & PRDX3 & 69 & 14.18 & 0.10 & $7.82 \mathrm{E}-33$ & $8.69 \mathrm{E}-34$ \\
\hline 206276_at & LY6D & 47 & 14.37 & 0.15 & $3.27 \mathrm{E}-32$ & $3.91 \mathrm{E}-33$ \\
\hline 201098 at & COPB2 & 42 & 15.65 & 0.07 & $3.17 \mathrm{E}-28$ & $4.07 \mathrm{E}-29$ \\
\hline 201653 at & CNIH1 & 87 & 16.31 & 0.067 & $2.05 \mathrm{E}-26$ & $2.80 \mathrm{E}-27$ \\
\hline 211906_s_at & SERPINB4 & 8 & 16.42 & 0.003 & $3.80 \mathrm{E}-26$ & $5.52 \mathrm{E}-27$ \\
\hline 202753 at & PSMD6 & 56 & 17.6 & 0.01 & $3.54 \mathrm{E}-23$ & $5.45 \mathrm{E}-24$ \\
\hline 202209 at & LSM3 & 15 & 17.92 & 0.004 & $1.97 \mathrm{E}-22$ & $3.20 \mathrm{E}-23$ \\
\hline 211023 at & PDHB & 9 & 17.95 & 0.018 & $2.14 \mathrm{E}-22$ & $3.66 \mathrm{E}-23$ \\
\hline 221896 s at & HIGD1A & 5 & 19.47 & 954.6 & 3.69E-19 & $6.62 \mathrm{E}-20$ \\
\hline 213164 at & SLC5A3 & 63 & 22.18 & 787.9 & $2.11 \mathrm{E}-14$ & $3.97 \mathrm{E}-15$ \\
\hline 201863 at & FAM32A & 106 & 22.74 & 767.2 & $1.42 \mathrm{E}-13$ & $2.78 \mathrm{E}-14$ \\
\hline 209694 at & PTS & 66 & 24.92 & 688.4 & $1.09 \mathrm{E}-10$ & $2.23 \mathrm{E}-11$ \\
\hline 218845 at & DUSP22 & 10 & 26.22 & 675.4 & $3.21 \mathrm{E}-09$ & $6.86 \mathrm{E}-10$ \\
\hline 203315 at & NCK2 & 80 & 27.84 & 584.5 & $1.28 \mathrm{E}-07$ & 2.84E-08 \\
\hline 213357 at & GTF2H5 & 114 & 28.09 & 612.8 & $2.09 \mathrm{E}-07$ & 4.83E-08 \\
\hline 217850 at & SNORD19B & 29 & 28.27 & 592.6 & $2.95 \mathrm{E}-07$ & $7.06 \mathrm{E}-08$ \\
\hline 218283 at & SS18L2 & 12 & 28.72 & 578.6 & 6.99E-07 & $1.73 \mathrm{E}-07$ \\
\hline 203282 at & GBE1 & 14 & 31.25 & 526.7 & $5.77 \mathrm{E}-05$ & $1.48 \mathrm{E}-05$ \\
\hline 212488 at & COL5A1 & 68 & 32.86 & 426.3 & 0.0005592 & 0.000148 \\
\hline 219389 at & SUSD4 & 48 & 34.36 & 439.2 & 0.003389 & 0.000927 \\
\hline 218115 at & ASF1B & 36 & 35.81 & 405 & 0.00481 & 0.004177 \\
\hline 201692 at & SIGMAR1 & 117 & 36.53 & 393 & 0.00775 & 0.008063 \\
\hline
\end{tabular}




\section{Table 4 (on next page)}

Ranking of each gene (upregulated) using proposed FS methods.

*The 9 upregulated genes selected by most ( $\geq 6$ ) of the methods are CNKSR2, PEG3, SPATA6, SPON1, BTD, AK026407, RPLP2, TCF3 and TMEM115. 
1 Ranking of each gene (upregulated) using proposed FS methods.

\begin{tabular}{|c|c|c|c|c|c|c|c|c|c|c|}
\hline ID REF & Identifier & $\mathrm{HC}$ & PCC & Relief-F & SFS & SVM-RFE & CFS & $\mathrm{RF}$ & IG & Score \\
\hline 206731 at & CNKSR2 & 1 & 1 & 1 & 1 & 1 & 1 & 1 & 1 & 8 \\
\hline 209243 s_at & PEG3 & 1 & 0 & 1 & 1 & 1 & 1 & 1 & 1 & 7 \\
\hline $210549 \mathrm{~s}$ at & CCL23 & 1 & 1 & 1 & 1 & 0 & 0 & 0 & 1 & 5 \\
\hline 216108 at & LOC105373738 & 1 & 1 & 1 & 0 & 0 & 1 & 0 & 1 & 5 \\
\hline 220298 s_at & SPATA6 & 1 & 1 & 1 & 1 & 1 & 0 & 1 & 1 & 7 \\
\hline 212797 at & SORT1 & 0 & 1 & 0 & 1 & 0 & 0 & 1 & 1 & 4 \\
\hline 207996 s at & LDLRAD4 & 0 & 1 & 0 & 1 & 0 & 0 & 0 & 0 & 2 \\
\hline 208762 at & SUMO1 & 0 & 1 & 0 & 0 & 0 & 0 & 1 & 1 & 3 \\
\hline 207257 at & EPO & 1 & 1 & 0 & 1 & 0 & 1 & 0 & 1 & 5 \\
\hline 202035 s_at & SFRP1 & 1 & 0 & 0 & 0 & 1 & 0 & 1 & 1 & 4 \\
\hline 204672 s at & ANKRD6 & 0 & 0 & 1 & 1 & 1 & 0 & 1 & 1 & 5 \\
\hline 220994 s at & STXBP6 & 0 & 0 & 1 & 1 & 1 & 0 & 1 & 1 & 5 \\
\hline 213652 at & PCSK5 & 1 & 0 & 0 & 0 & 1 & 1 & 0 & 0 & 3 \\
\hline 213994 s at & SPON1 & 1 & 0 & 1 & 1 & 1 & 1 & 1 & 0 & 6 \\
\hline 221606 s_at & HMGN5 & 0 & 0 & 1 & 1 & 1 & 1 & 1 & 0 & 5 \\
\hline 203440 at & $\mathrm{CDH} 2$ & 1 & 0 & 1 & 1 & 0 & 1 & 0 & 1 & 5 \\
\hline 207046 at & HIST2H4B & 1 & 0 & 0 & 0 & 0 & 0 & 0 & 0 & 1 \\
\hline $211865 \mathrm{~s}$ at & FZR1 & 0 & 1 & 1 & 1 & 0 & 1 & 0 & 1 & 5 \\
\hline 215401 at & AU147698 & 1 & 0 & 1 & 0 & 1 & 1 & 0 & 1 & 5 \\
\hline 213068 at & DPT & 1 & 0 & & 0 & 0 & 1 & 1 & 1 & 5 \\
\hline 214117_s_at & BTD & 1 & 1 & 0 & 1 & 1 & 1 & 1 & 1 & 7 \\
\hline 34187 at & AK026407 & 1 & 1 & 0 & 1 & 1 & 0 & 1 & 1 & 6 \\
\hline 213611 at & AQP5 & 1 & 0 & 0 & 1 & 1 & 1 & 1 & 0 & 5 \\
\hline 209465_x_at & PTN & 0 & 0 & 1 & 0 & 1 & 1 & 0 & 0 & 3 \\
\hline 208606 s at & WNT4 & 0 & 0 & 1 & 1 & 1 & 1 & 1 & 0 & 5 \\
\hline $211814 \mathrm{~s}$ at & CCNE2 & 0 & 0 & 1 & 1 & 1 & 1 & 1 & 0 & 5 \\
\hline $208790 \_$s_at & PTRF & 0 & 0 & 0 & 0 & 0 & 1 & 0 & 0 & 1 \\
\hline 200908 s at & RPLP2 & 1 & 1 & 1 & 1 & 1 & 0 & 1 & 1 & 7 \\
\hline 219795 at & SLC6A14 & 0 & 0 & 0 & 0 & 1 & 1 & 0 & 0 & 2 \\
\hline 205730_s_at & ABLIM3 & 1 & 0 & 1 & 0 & 1 & 1 & 1 & 0 & 5 \\
\hline 202648 at & TCF3 & 1 & 1 & 1 & 1 & 0 & 1 & 1 & 1 & 7 \\
\hline 216267 s_at & TMEM115 & 1 & 1 & 1 & 0 & 1 & 0 & 1 & 1 & 6 \\
\hline
\end{tabular}




\section{Table 5 (on next page)}

Ranking of each gene (downregulated) using proposed FS methods.

*The 12 downregulated genes selected by most ( $\geq 6$ ) of the methods are RPL15, HIGDIA, ARL6IP5, PRDX3, COPB2, CNIH1, PSMD6, LSM3, PDHB, SLC5A3, PTS and ASF1B. As gene HIGDIA is selected twice with different ID REF, it only considered once here. 
1 Ranking of each gene (downregulated) using proposed FS methods.

\begin{tabular}{|c|c|c|c|c|c|c|c|c|c|c|}
\hline ID REF & Identifier & $\mathrm{HC}$ & $\mathrm{PCC}$ & Relief-F & SFS & SVM-RFE & CFS & $\mathrm{RF}$ & IG & Score \\
\hline 221475 s_at & RPL15 & 1 & 1 & 1 & 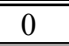 & 1 & 1 & 1 & 1 & 7 \\
\hline 203535 at & S100A9 & 0 & 0 & 0 & 1 & 1 & 1 & 1 & 0 & 4 \\
\hline 209719 x at & SERPINB3 & 0 & 0 & 0 & 0 & 1 & 1 & 0 & 0 & 2 \\
\hline 200074 s_at & GUK1 & 1 & 0 & 1 & 0 & 0 & 0 & 1 & 0 & 3 \\
\hline 209351_at & KRT14 & 0 & 0 & 1 & 0 & 0 & 1 & 0 & 0 & 2 \\
\hline 201097 s_at & ARF4 & 1 & 1 & 0 & 1 & 0 & 0 & 0 & 1 & 4 \\
\hline 217845 x_at & HIGD1A & 1 & 1 & 1 & 1 & 1 & 0 & 1 & 1 & 7 \\
\hline $210413 \mathrm{x}$ at & SERPINB4 & 0 & 1 & 0 & 0 & 1 & 1 & 1 & 0 & 4 \\
\hline 210835 s at & CTBP2 & 1 & 0 & 0 & 0 & 0 & 1 & 1 & 1 & 4 \\
\hline 209720 s_at & SERPINB3 & 0 & 1 & 0 & 1 & 0 & 0 & 1 & 0 & 3 \\
\hline 200761 s at & ARL6IP5 & 1 & 1 & 1 & 1 & 1 & 0 & 1 & 0 & 6 \\
\hline 201619 at & PRDX3 & 1 & 1 & 1 & 1 & 1 & 1 & 0 & 1 & 7 \\
\hline 206276 at & LY6D & 0 & 0 & 1 & 0 & 1 & 1 & 0 & 0 & 3 \\
\hline 201098 at & COPB2 & 1 & 1 & 1 & 1 & 1 & & 1 & 1 & 7 \\
\hline 201653 at & CNIH1 & 1 & 1 & 1 & 1 & 0 & 1 & 1 & 1 & 7 \\
\hline 211906 s_at & SERPINB4 & 0 & 1 & 0 & 1 & 0 & 1 & 0 & 0 & 3 \\
\hline 202753 at & PSMD6 & 1 & 1 & 0 & 1 & 1 & 0 & 1 & 1 & 6 \\
\hline 202209 at & LSM3 & 1 & 1 & 1 & 1 & 1 & 1 & 0 & 0 & 6 \\
\hline 211023 at & PDHB & 1 & 1 & 1 & 1 & 1 & 1 & 1 & 1 & 8 \\
\hline $221896 \mathrm{~s}$ at & HIGD1A & 1 & 1 & 1 & 1 & 1 & 0 & 1 & 0 & 6 \\
\hline 213164_at & SLC5A3 & 1 & 0 & 0 & 1 & 1 & 1 & 1 & 1 & 6 \\
\hline 201863 at & FAM32A & 1 & 1 & 1 & 0 & 0 & 0 & 0 & & 4 \\
\hline 209694 at & PTS & 1 & 1 & 1 & 1 & 1 & 1 & 0 & 0 & 6 \\
\hline 218845 at & DUSP22 & 1 & 0 & 1 & 0 & 1 & 0 & 1 & 1 & 5 \\
\hline 203315 at & NCK2 & 1 & 0 & 0 & 1 & 1 & 0 & 1 & 1 & 5 \\
\hline 213357 at & GTF2H5 & 1 & 1 & 1 & 0 & 0 & 0 & 0 & 1 & 4 \\
\hline 217850 at & SNORD19B & 1 & 1 & 0 & 1 & 0 & 1 & 0 & 1 & 5 \\
\hline 218283 at & SS18L2 & 1 & 1 & 0 & 0 & 0 & 0 & 0 & 1 & 3 \\
\hline 203282 at & GBE1 & 1 & 1 & 1 & 0 & 0 & 1 & 0 & 1 & 3 \\
\hline 212488_at & COL5A1 & 1 & 0 & 1 & 0 & 0 & & 0 & 0 & 3 \\
\hline 219389 at & SUSD4 & 1 & 0 & 0 & 1 & 1 & 0 & 1 & 0 & 4 \\
\hline 218115 at & ASF1B & 1 & 0 & 1 & 1 & 1 & 1 & 1 & 1 & 7 \\
\hline 201692 at & SIGMAR1 & 1 & 0 & 1 & 0 & 0 & 1 & 1 & 1 & 5 \\
\hline
\end{tabular}




\section{Table 6(on next page)}

Results of GSEA analysis using the 9 upregulated-genes.

*There was no matching of gene AK026407, TCF3 and TMEM115 with the MSigDB. 
1 Results of GSEA analysis using the 9 upregulated-genes.

\begin{tabular}{|l|l|l|l|}
\hline & $\begin{array}{l}\text { Highest Normalized } \\
\text { Enrichment Score } \\
\text { Identifier }\end{array}$ & FDR q-value & Status \\
\hline CNKSR2 & 1.00 & 0.859 & Rejected \\
\hline PEG3 & 1.33 & 0.000 & Pass \\
\hline SPATA6 & 1.00 & 0.823 & Rejected \\
\hline SPON1 & 1.60 & 0.053 & Pass \\
\hline BTD & 1.50 & 0.026 & Pass \\
\hline AKO26407 & - & - & - \\
\hline RPLP2 & 1.40 & 0.000 & Pass \\
\hline TCF3 & - & - & - \\
\hline TMEM115 & - & - & - \\
\hline
\end{tabular}

2 


\section{Table 7 (on next page)}

Results of GSEA analysis using the 12 downregulated-genes.

*There was no matching of gene ARL6IP5, CNIH1 and PTS with the MSigDB. 
1 Results of GSEA analysis using the 12 downregulated-genes.

\begin{tabular}{|l|l|l|l|}
\hline Identifier & $\begin{array}{l}\text { Highest Normalized } \\
\text { Enrichment Score (ES) }\end{array}$ & FDR q-value & Status \\
\hline RPL15 & 1.21 & 0.779 & Rejected \\
\hline HIGD1A & 1.25 & 1.00 & Rejected \\
\hline ARL6IP5 & - & - & - \\
\hline PRDX3 & 1.41 & 0.020 & Pass \\
\hline COPB2 & 1.41 & 0.020 & Pass \\
\hline CNIH1 & - & - & - \\
\hline PSMD6 & 1.44 & 0.560 & Rejected \\
\hline LSM3 & 1.41 & 0.020 & Pass \\
\hline PDHB & 1.33 & 0.839 & Rejected \\
\hline$S L C 5 A 3$ & 1.50 & 0.000 & Pass \\
\hline$P T S$ & - & - & - \\
\hline$A S F 1 B$ & 1.43 & 0.000 & Pass \\
\hline
\end{tabular}

2 


\section{Table 8 (on next page)}

Function, related diseases and description of the most significant genes (Upregulated). 
1 Function, related diseases and description of the most significant (Upregulated).

\begin{tabular}{|c|c|c|c|}
\hline GENES & FULL NAME & FUNCTION & $\begin{array}{l}\text { RELATED DISEASES AND } \\
\text { DESCRIPTION }\end{array}$ \\
\hline PEG3 & $\begin{array}{l}\text { Paternally } \\
\text { Expressed } \\
\text { Gene } 3\end{array}$ & - protein coding gene. & $\begin{array}{l}\text { - Hypermethylation of PEG3 is linked } \\
\text { to epigenetics mechanism and HPV } \\
\text { infection in cervical intraepithelial } \\
\text { neoplasia (CIN) and Invasive Cervical } \\
\text { Cancer. [40] } \\
\text { - Cell proliferation and p53-mediated } \\
\text { apoptosis. [41] } \\
\text { - Involvement in the glioma and ovarian } \\
\text { cancers. [42] }\end{array}$ \\
\hline SPON1 & F-spondin 1 & $\begin{array}{l}\text { - extracellular matrix } \\
\text { organization regulation, } \\
\text { interaction between cells } \\
\text { and axon guidance. [43] }\end{array}$ & $\begin{array}{l}\text { - Showed extreme expression activities } \\
\text { in the identification of colorectal } \\
\text { biomarkers. [44] } \\
\text { - Down regulation activity in the } \\
\text { cervical cell carcinoma. [45] }\end{array}$ \\
\hline$B T D$ & bitonidase & $\begin{array}{l}\text { gene expression, } \\
\text { proliferation and } \\
\text { differentiation of cells, } \\
\text { gene signaling. [46] }\end{array}$ & $\begin{array}{l}\text { - gene expression signature that marks } \\
\text { pelvic lymph node metastasis (PLNM) } \\
\text { in cervical carcinoma. [47] } \\
\text { - Involvement in thyroid and lung } \\
\text { cancers }[48,49] \\
\text { - Potential serological marker in breast } \\
\text { cancer plasma. [50] }\end{array}$ \\
\hline RPLP2 & $\begin{array}{l}\text { Ribosomal } \\
\text { Protein Lateral } \\
\text { Stalk Subunit } \\
\text { P2 }\end{array}$ & $\begin{array}{l}\text { - encodes a } 60 \text { s subunit } \\
\text { ribosomal protein. }\end{array}$ & $\begin{array}{l}\text { - prognostic marker for gastric cancer. } \\
\text { [51] } \\
\text { - involved in the carcinogenesis and } \\
\text { progression of various cancers. [52] } \\
\text { - associated with other ribosomal } \\
\text { protein genes with colorectal } \\
\text { carcinomas (CRC). [53] }\end{array}$ \\
\hline
\end{tabular}


Table 9 (on next page)

Function, related diseases and description of the most significant genes (Downregulated). 
1 Function, related diseases and description of the most significant genes (Downregulated).

\begin{tabular}{|c|c|c|c|}
\hline GENES & FULL NAME & FUNCTION & $\begin{array}{c}\text { RELATED DISEASES AND } \\
\text { DESCRIPTION }\end{array}$ \\
\hline PRDX3 & Peroxiredoxin3 & $\begin{array}{l}\text { - encodes antioxidant function } \\
\text { protein, provides protection to } \\
\text { mitochondria from oxidative } \\
\text { stress. [55] } \\
\text { - regulates the cellular Reactive } \\
\text { Oxidative Species (ROS) level } \\
\text { of the cell. [56] }\end{array}$ & $\begin{array}{l}\text { - showed correlation with the severity } \\
\text { of the cervical carcinoma [57]. } \\
\text { - Showed immunopositivity to be } \\
\text { significantly higher in cervical } \\
\text { cancer cells [58] }\end{array}$ \\
\hline COPB2 & $\begin{array}{l}\text { Coatomer } \\
\text { Protein } \\
\text { Complex } \\
\text { Subunit Beta 2 }\end{array}$ & $\begin{array}{l}\text { - protein coding gene. } \\
\text { - involves in the transduction of } \\
\text { signal for G protein. [59] }\end{array}$ & $\begin{array}{l}\text { One of the differentially expressed } \\
\text { genes in LNCaP prostate cancer } \\
\text { cell lines. [60] }\end{array}$ \\
\hline LSM3 & $\begin{array}{l}\text { Hypothetical } \\
\text { protein } \\
\text { LOC285378 }\end{array}$ & $\begin{array}{l}\text { - Involves in the process of } \\
\text { MRNA splicing }\end{array}$ & $\begin{array}{l}\text { - Involved in the rapid proliferation, } \\
\text { invasiveness, oxidative } \\
\text { phosphorylation and tumor size of } \\
\text { cervical cancers. [61] }\end{array}$ \\
\hline$S L C 5 A 3$ & $\begin{array}{l}\text { Solute Carrier } \\
\text { Family } 5 \\
\text { Member } 3\end{array}$ & $\begin{array}{l}\text { - Involves in the } \\
\text { osmoregulation of cells. [62] } \\
\text { - prevents the impairment of } \\
\text { cell cellular function [63] }\end{array}$ & $\begin{array}{l}\text { - differentially expressed between } \\
\text { Parental SiHa Cells and } \mathrm{SiHa} / \mathrm{R} \\
\text { Cells of cervical cancer. [64] } \\
\text { - involved in the formation of fusion } \\
\text { transcripts gene in some prostate } \\
\text { cancer cases. [65] }\end{array}$ \\
\hline$A S F 1 B$ & $\begin{array}{l}\text { Anti-Silencing } \\
\text { Function 1B } \\
\text { Histone } \\
\text { Chaperone }\end{array}$ & $\begin{array}{l}\text { - codes for the substrate protein } \\
\text { of the cycle regulated-kinase } \\
\text { cell. } \\
\text { - derepress the overexpression } \\
\text { of transcriptional silencing. } \\
\text { [66] }\end{array}$ & $\begin{array}{l}\text { - associated with the aggressiveness } \\
\text { of breast tumor. [67] } \\
\text { leaded to the poor disease outcome } \\
\text { in the study of the cervical cancer } \\
\text { proliferation cluster that } \\
\text { corresponding to the } 163 \text { transcripts } \\
\text { [68]. }\end{array}$ \\
\hline
\end{tabular}

